\title{
A CAUSE OF THE THROMBOCYTOPENIA AND LEUKOPENIA THAT OCCUR IN DOGS DURING DEEP HYPOTHERMIA
}

\author{
By TULIO J. VILLALOBOS, ${ }^{1}$ EDWARD ADELSON, PHILIP A. RILEY, JR., ${ }^{2}$ AND \\ WILLIAM H. CROSBY WITH THE TECHNICAL ASSISTANCE OF \\ HAROLD GLAUCKE \\ (From the Department of Hematology, Walter Reed Army Institute of Research, Walter \\ Reed Army Medical Center, Washington, D. C.)
}

(Submitted for publication June 17, 1957; accepted September 5, 1957)

A previous report from this laboratory (1) presented the results of hematologic studies in nine dogs cooled below $20^{\circ} \mathrm{C}$. During induction of hypothermia the animals showed a marked rise in red cell count, hemoglobin, and hematocrit, together with a nearly complete disappearance of white cells and platelets. On rewarming, the values all returned to normal. A number of studies have been carried out to learn more about the mechanism of these changes. The present paper describes some of the studies dealing especially with the changes in platelets and white cells.

\section{MATERIALS AND METHODS}

The experiments were performed on a group of 22 adult mongrel dogs. Hypothermia was induced by a method of surface cooling previously reported (2). Each dog was anesthetized with intravenous thiopental. An endotracheal catheter was inserted and connected to an automatic respirator utilizing room air. Thermocouples in the rectum and esophagus permitted continuous temperature recordings by a Brown potentiometer. A continuous three limb lead electrocardiogram and aortic blood pressure were also recorded. The animal was placed in an ice bath at $4^{\circ} \mathrm{C}$. and cooled until ventricular fibrillation occurred or the rectal temperature reached $17^{\circ} \mathrm{C}$. The heart was defibrillated electrically. Each experiment, from the onset of hypothermia until rewarming had raised the body temperature to approximately $30^{\circ}$ C., occupied approximately five hours. Platelet counts were carried out by the method of Brecher and Cronkite (3) using phase microscopy. Two pipettes were filled and two chambers for each pipette were counted and the average was taken as the result for each determination. By this technique, the normal range for platelet counts in dogs is 200,000 to 350,000 per cu. mm. Leukocyte counts were carried out by the standard hemocytometer technique using $1: 20 \mathrm{di}-$ lution. Both sides of two hemocytometer chambers were

\footnotetext{
1 Present address: Banco de Sangre del Distrito Federal, Caracas, Venezuela.

2 Department of Experimental Surgery, Walter Reed Army Institute of Research.
}

counted. Hemoglobin concentration was measured by the cyanmethemoglobin method (4). Hematocrit was measured in capillary tubes after high-speed centrifugation (5).

Protocol 1: Bone marrow aspirations and biopsies were carried out from the ribs and tibias of three dogs before, during, and after hypothermia.

Protocol 2: Studies with radioactive platelets were carried out in dogs using a donor (Dog $\mathrm{A}$ ) and a recipient (Dog B). Two mc. of $\mathrm{P}^{22}\left(\mathrm{NaHP}^{32} \mathrm{O}_{4}\right.$, Abbott) was injected into Dog A. One week later, Dog A was bled by cardiac puncture, and $500 \mathrm{ml}$. of blood was drawn into a plastic bag containing disodium versinate solution. Simultaneously $500 \mathrm{ml}$. of blood was taken from Dog B. Dog B was then transfused immediately with the blood from Dog A containing radioactive platelets. Onehalf hour later, using siliconized equipment and a two syringe technique, $15 \mathrm{ml}$. of blood was taken from Dog B. Platelets and plasma were separated from red cells by differential centrifugation and the platelets were counted in a hemocytometer chamber using a phasecontrast microscope. The platelet suspension was then centrifuged to throw down the platelets. The platelets were washed three times with saline and transferred to an aluminum planchet and the $\mathrm{P}^{32}$ radioactivity was measured in a Geiger-Müller counter with a window thickness of $2.2 \mathrm{mg}$. per $\mathrm{cm}^{2}$ (Tracerlab). Leukocyte, erythrocyte, and platelet counts, using standard methods, were also performed on the whole blood. Dog B, anesthetized with Pentothal ${ }^{\circledR}$, was then placed in ice until his body temperature fell to $17^{\circ} \mathrm{C}$. and his platelet count fell from 204,000 to 58,000 . He was then rewarmed. When his platelet count had risen, a second $15 \mathrm{ml}$. sample of blood was drawn and the procedure of counting described above was repeated.

Protocol 3: Platelet counts were done on blood obtained directly from various organs of six hypothermic dogs (Numbers 11, 12,13,16, 17 and 18) by making small stab incisions. These counts were compared with counts performed on blood obtained simultaneously from the aorta by means of a polyethylene catheter threaded up the femoral artery.

Protocol 4: Biopsies were taken from skeletal muscles, skin, spleen, liver, kidney, lung, and heart of four animals (Numbers 11, 12, 13 and 17) at the height of hypothermia. These tissue sections were fixed in isotonic, 
TABLE I

Hypothermia in a dog (number 32 ) with radioactive platelets

\begin{tabular}{lcc}
\hline \hline & $\begin{array}{c}\text { Platelet } \\
\text { radioactivity } \\
\text { Platelets/ } \\
\text { cu. mm. }\end{array}$ & $\begin{array}{c}\text { counts/platelet/ } \\
\text { second }\end{array}$ \\
\hline $\begin{array}{l}\text { Before hypothermia } \\
\text { Maximal hypothermia }\end{array}$ & $\begin{array}{r}204,000 \\
58,000\end{array}$ & $3.7 \times 10^{-9}$ \\
After hypothermia & 225,000 & $3.0 \times 10^{-9}$ \\
\hline
\end{tabular}

buffered formalin and stained with hematoxylin-eosin and Giemsa stains.

Protocol 5a: In three dogs (Numbers 11, 12 and 13) after anesthesia was induced but prior to cooling, two polyethylene catheters were set in place, one in the aorta by threading it up the femoral artery, and the other via the femoral vein in the inferior vena cava almost to the level of the right auricle. Samples of blood were taken from both catheters at intervals during the time of cooling and rewarming and counts were done. In a control experiment an animal was manipulated in the same manner except that hypothermia was not induced. The leukocyte and platelet counts did not significantly vary during the six hour period of manipulation and anesthesia (Table IV). This serves to demonstrate that the alterations of these counts which regularly occurred during hypothermia and rewarming were not due to such variables as time, anesthesia, trauma or the presence of catheters.

b. The procedure was that of protocol 5a except that the tip of the intravenous catheter was in the vena cava below the level of the renal vein in dogs Number 16 and 17.

c. As in protocol $5 \mathrm{a}$ but with three catheters; one in the aorta, one in low inferior vena cava, and one in the hepatic vein. The latter catheter was placed by direct observation during laparotomy. This was done in three dogs (Numbers 18, 19 and 20).

d. As in protocol $5 \mathrm{a}$, but with catheters in the aorta, low inferior vena cava, hepatic vein, and in the portal vein just as it entered the liver. The latter two catheters were placed under direct observation during laparotomy. Because of the technical difficulties of this procedure only one animal was adequately studied, although the experiment was done five times (Dogs 21, 22, 23, 24 and 25).

Protocol 6a: Splenectomy was performed on two healthy dogs (Numbers 14 and 15) and they were allowed

TABLE II

Platelet counts from incised wounds of various organs, done at maximum hypothermia $\left(20^{\circ} \mathrm{C}\right.$.)

\begin{tabular}{lcccr}
\hline \hline Dog no. & Aorta & Spleen & Liver & \multicolumn{1}{c}{ Lung } \\
\hline 11 & 28,500 & 31,500 & 10,000 & 6,000 \\
12 & 24,000 & 55,000 & 13,500 & 10,000 \\
13 & 68,500 & 59,500 & 20,500 & 11,500 \\
18 & 41,000 & 38,500 & 25,500 & 20,000 \\
\hline
\end{tabular}

to recover from the operation. One week later protocol 5 a was carried out.

b. Hepatectomy was performed on two healthy dogs (Numbers 26 and 27). The incision was closed and shortly thereafter they were cooled. In these experiments samples of blood were taken only from the aorta.

c. Combined splenectomy and hepatectomy were performed in four dogs (Numbers 28, 29, 30 and 31) and the animals were immediately cooled. Specimens were taken from catheters placed in the upper and the lower inferior vena cava, and from the aorta.

\section{RESULTS}

As previously reported, the platelet and leukocyte counts fell during the cooling and returned to the normal range when the animals were rewarmed. In general the changes in the leukocyte counts were not so great as the changes in platelet counts nor so consistent.

\section{Protocol 1}

Bone marrow aspirations and biopsies reveal no differences in the megakaryocytes seen before, during, or after the hypothermic state. Platelet formation and platelet morphology also appeared unchanged.

\section{Protocol 2}

Table I summarizes the results of the radioactive platelet transfusion. This table demonstrates that the platelets which appeared in the circulation following rewarming of the hypothermic dogs had 80 per cent of the radioactivity of the platelets present prior to hypothermia. In other words, 80 per cent of the radioactive platelets present prior to hypothermia reappeared on rewarming. An analysis of this matter has been published elsewhere (6).

\section{TABLE III}

Platelet counts in a dog (number 10) during deep hypothermia - a comparison of counts taken by catheter from the aorta and from incised wounds of the tongue

\begin{tabular}{crr}
\hline & \multicolumn{2}{c}{ Platelets/cu. mm. } \\
\cline { 2 - 3 } Temperature & Aorta & $\begin{array}{c}\text { Capillaries } \\
\text { (tongue) }\end{array}$ \\
\hline${ }^{\circ}{ }^{\circ}$ C. $)$ & & \\
37 & 445,000 & 339,000 \\
25 & 213,000 & 199,000 \\
20 & 28,500 & 33,000 \\
25 & 75,000 & 71,500 \\
30 & 451,000 & 466,000 \\
\hline
\end{tabular}


TABLE IV

Blood counts during deep hypothermia (dog number 13)-a comparison of counts from the aorta and high in the inferior vena cava

\begin{tabular}{|c|c|c|c|c|c|c|}
\hline \multirow[b]{2}{*}{ Temperature } & \multicolumn{3}{|c|}{ Aorta } & \multicolumn{3}{|c|}{ High vena cava } \\
\hline & Platelets & Hemoglobin & Leukocytes & Platelets & Hemoglobin & Leukocytes \\
\hline$\left({ }^{\circ} \mathrm{C}.\right)$ & (percu.mm.) & $(G m . \%)$ & (per cu.mm.) & (per cu. mm.) & $(\mathrm{Gm} . \%)$ & (per cu. mm.) \\
\hline $\begin{array}{l}37 \\
25 \\
20 \\
25 \\
30\end{array}$ & $\begin{array}{r}332,000 \\
183,000 \\
68,500 \\
144,500 \\
220,000\end{array}$ & $\begin{array}{l}13.6 \\
16.2 \\
19.3 \\
14.7 \\
12.4\end{array}$ & $\begin{array}{r}14,800 \\
10,900 \\
6,250 \\
8,800 \\
10,850\end{array}$ & $\begin{array}{r}298,000 \\
131,000 \\
35,000 \\
195,000 \\
249,000\end{array}$ & $\begin{array}{l}13.3 \\
15.7 \\
18.7 \\
12.7 \\
13.1\end{array}$ & $\begin{array}{r}15,950 \\
13,250 \\
6,500 \\
9,850 \\
11,850\end{array}$ \\
\hline \multicolumn{7}{|c|}{ Blood counts on control dog (no hypothermia) } \\
\hline $\begin{array}{l}1 \text { hour } \\
2 \text { hours } \\
4 \text { hours } \\
5 \text { hours } \\
6 \text { hours }\end{array}$ & $\begin{array}{l}387,000 \\
395,000 \\
357,000 \\
348,000 \\
376,000\end{array}$ & & $\begin{array}{l}36,600 \\
39,150 \\
37,150 \\
55,900 \\
50,000\end{array}$ & $\begin{array}{l}393,000 \\
380,000 \\
420,000 \\
379,000 \\
385,000\end{array}$ & & $\begin{array}{l}36,000 \\
36,750 \\
33,800 \\
49,000 \\
47,100\end{array}$ \\
\hline
\end{tabular}

\section{Protocol 3}

Table II demonstrates a similar decline in platelet counts obtained before and during deep hypothermia from aorta, spleen, liver and lung. The platelet counts of blood from the spleen and the lung tended to be lower than the others, but these experiments did not uncover any site of platelet storage. Blood from the cut tongue had changes in platelet counts that closely resembled those from the aorta (Table III).

\section{Protocol 4}

Biopsies taken from various organs at the height of hypothermia revealed no histological evidence of platelet storage.

\section{Protocol $5 a$}

Table IV demonstrates the results of platelet and leukocyte counts carried out simultaneously from catheters in the aorta and in the inferior vena cava proximal to the entrance of the hepatic vein. The drop in platelets high in the inferior vena cava preceded the drop in platelets in the aorta during the cooling process. During the warming phase, the rise in platelet counts from samples taken high in the inferior vena cava preceded the rise in the aortic samples. Platelets were apparently filtered out somewhere between the aorta and high in the inferior vena cava during cooling, and were being released from this site during rewarming. This would rule out the pulmonary circulation as the site of platelet sequestration.

$b$. Table $\mathrm{V}$ shows the results obtained when the tip of the catheter in the vena cava was lowered so that it no longer obtained blood from both the systemic and portal systems. During cooling the caval platelet and leukocyte counts did not fall more rapidly than the aortic counts.

c. In Table VI are the results from hypothermic dogs with catheters placed in the aorta, low inferior vena cava and hepatic vein. Platelet and leukocyte counts from the hepatic vein fell more rapidly than those from the other vessels. During rewarming the counts from the hepatic vein

TABLE V

Blood counts in a dog (number 17) during hypothermia-a comparison of counts from the aorta and low in the inferior vena cava

\begin{tabular}{|c|c|c|c|c|}
\hline \multirow[b]{2}{*}{ Temperature } & \multicolumn{2}{|c|}{ Aorta } & \multicolumn{2}{|c|}{ Low vena cava } \\
\hline & Platelets & Leukocytes & Platelets & Leukocytes \\
\hline$\left({ }^{\circ} \mathrm{C}.\right)$ & (percu.mm.) & (per cu.mm.) & (per cu.mm.) & (per cu. mm.) \\
\hline $\begin{array}{l}37 \\
25 \\
20\end{array}$ & $\begin{array}{r}299,500 \\
123,000 \\
48,500\end{array}$ & $\begin{array}{r}15,000 \\
8,600 \\
8,000\end{array}$ & $\begin{array}{r}342,500 \\
117,500 \\
47,500\end{array}$ & $\begin{array}{r}13,000 \\
9,900 \\
8,800\end{array}$ \\
\hline
\end{tabular}


TABLE VI

Blood counts during deep hypothermia (dog number 20)—a comparison of counts from the aorta, low in the inferior vena cava, and from the hepatic vein

\begin{tabular}{|c|c|c|c|c|c|c|}
\hline \multirow[b]{2}{*}{ Temperature } & \multicolumn{3}{|c|}{ Platelets } & \multicolumn{3}{|c|}{ Leukocytes } \\
\hline & Aorta & $\begin{array}{l}\text { Low vena } \\
\text { cava }\end{array}$ & $\underset{\text { vein }}{\text { Hepatic }}$ & Aorta & $\begin{array}{l}\text { Low vena } \\
\text { cava }\end{array}$ & $\underset{\text { vein }}{\text { Hepatic }}$ \\
\hline$\left({ }^{\circ} \mathrm{C}.\right)$ & \multicolumn{3}{|c|}{ (per cu. mm.) } & \multicolumn{3}{|c|}{ (per cu.mm.) } \\
\hline $\begin{array}{l}37 \\
25 \\
20 \\
25 \\
30\end{array}$ & $\begin{array}{r}374,000 \\
91,000 \\
48,000 \\
177,000 \\
163,500\end{array}$ & $\begin{array}{r}336,000 \\
108,000 \\
42,500 \\
199,500 \\
226,500\end{array}$ & $\begin{array}{r}363,000 \\
74,500 \\
30,000 \\
201,000 \\
189,000\end{array}$ & $\begin{array}{l}7,000 \\
2,600 \\
1,400 \\
2,300 \\
3,800\end{array}$ & $\begin{array}{l}5,900 \\
3,000 \\
1,800 \\
3,700 \\
5,000\end{array}$ & $\begin{array}{l}6,000 \\
2,000 \\
1,200 \\
3,900 \\
5,500\end{array}$ \\
\hline
\end{tabular}

increased more rapidly than those from other vessels.

$d$. In Table VII, the results of platelet and white cell counts from catheters in the aorta, low inferior vena cava, portal vein, and hepatic vein are compared. The changes in platelet count in the hepatic and portal veins preceded the changes in the aorta and low inferior vena cava when decreasing and also when increasing. Because the changes in the hepatic vein preceded those in the portal vein, it is evident that the liver plays a considerable role in platelet sequestration. However, because the changes in portal vein preceded those in the inferior vena cava and the aorta there may be other sites of sequestration in the portal circulation.

\section{Protocol 6a}

Table VIII demonstrates that splenectomy does not significantly alter the response of the platelets, leukocytes, or hemoglobin during hypothermia. Furthermore, a comparison of the aortic counts with those of the high inferior vena cava (Table IX) indicates that the portal circulation may still be the major site of sequestration, even after splenectomy, although only the difference at the $25^{\circ} \mathrm{C}$. (on rewarming) level is within the 95 per cent confidence limit.

$b$. The effects of total hepatectomy on the platelet counts in hypothermia are shown in Table VIII. Because of the magnitude of the surgical procedures, these animals did not show the characteristic rise in hematocrit. These results indicate that while the liver plays some role in this phenomenon, it may not be the major site of sequestration.

c. Table VIII also shows the results of combined hepatectomy and splenectomy prior to hypothermia. Only one of the four dogs in this group showed the characteristic rise in hematocrit. Again this may be explained by the magnitude of the surgical procedures and the associated blood loss. In each of the four dogs, the platelet and white cell loss was less than that seen in animals which did not have hepatectomysplenectomy. Table $\mathrm{X}$ shows that there was no longer any significant difference in counts obtained high in the inferior vena cava and those obtained lower in the vena cava.

TABLE VII

Blood counts in a dog (number 19) during hypothermia - a comparison of counts from the aorta, low in the inferior vena cava, portal vein, and hepatic vein

\begin{tabular}{|c|c|c|c|c|c|c|c|c|}
\hline \multirow[b]{2}{*}{$\underset{\text { ture }}{\text { Tempera- }}$} & \multicolumn{4}{|c|}{ Platelets } & \multicolumn{4}{|c|}{ Leukocytes } \\
\hline & Aorta & $\begin{array}{c}\text { Low vena } \\
\text { cava }\end{array}$ & $\begin{array}{c}\text { Portal } \\
\text { vein }\end{array}$ & $\begin{array}{c}\text { Hepatic } \\
\text { vein }\end{array}$ & Aorta & $\begin{array}{l}\text { Low vena } \\
\text { cava }\end{array}$ & $\begin{array}{c}\text { Portal } \\
\text { vein }\end{array}$ & $\begin{array}{c}\text { Hepatic } \\
\text { vein }\end{array}$ \\
\hline$\left({ }^{\circ} \mathrm{C}.\right)$ & \multicolumn{4}{|c|}{ (per cu. mm.) } & \multicolumn{4}{|c|}{ (per cu. mm.) } \\
\hline $\begin{array}{l}37 \\
25 \\
20 \\
25 \\
30\end{array}$ & $\begin{array}{r}242,000 \\
106,000 \\
27,000 \\
64,000 \\
129,500\end{array}$ & $\begin{array}{r}233,000 \\
82,000 \\
23,000 \\
73,000 \\
126,000\end{array}$ & $\begin{array}{r}212,000 \\
53,500 \\
21,000 \\
77,500 \\
141,500\end{array}$ & $\begin{array}{r}146,500 \\
40,000 \\
11,500 \\
101,000 \\
150,000\end{array}$ & $\begin{array}{r}18,400 \\
6,300 \\
4,000 \\
6,000 \\
7,700\end{array}$ & $\begin{array}{r}18,200 \\
8,400 \\
5,300 \\
7,900\end{array}$ & $\begin{array}{r}11,600 \\
6,000 \\
3,800 \\
4,000 \\
8,300\end{array}$ & $\begin{array}{r}11,200 \\
8,300 \\
4,100 \\
5,900 \\
7,900\end{array}$ \\
\hline
\end{tabular}


MECHANISM OF HEMATOLOGIC CHANGES IN HYPOTHERMIC DOGS

TABLE VIII

Blood counts in splenectomized and hepatectomized dogs during hypothermia*

\begin{tabular}{|c|c|c|c|c|c|c|c|c|}
\hline \multirow{2}{*}{$\begin{array}{c}\text { Dog No. } 15 \\
\text { Tempera- } \\
\text { ture }\end{array}$} & \multicolumn{4}{|l|}{ Splenectomy } & & \multicolumn{3}{|c|}{ High vena cava } \\
\hline & & Platelets & Hct. & Leukocytes & & Platelets & Het. & Leukocytes \\
\hline $\begin{array}{c}\left({ }^{\circ} \mathrm{C} .\right) \\
37 \\
25 \\
20 \\
25 \\
30\end{array}$ & & $\begin{array}{c}\text { (per cu. mm.) } \\
369,500 \\
138,000 \\
42,500 \\
75,500 \\
198,500\end{array}$ & $\begin{array}{l}14.3 \\
15.7 \\
16.4 \\
15.1 \\
16.2\end{array}$ & $\begin{array}{c}\text { (per cu. mm.) } \\
24,900 \\
8,200 \\
5,200 \\
6,600 \\
12,600\end{array}$ & & $\begin{array}{c}\text { (per cu. mm.) } \\
262,000 \\
108,000 \\
34,000 \\
95,000 \\
167,000\end{array}$ & $\begin{array}{l}13.8 \\
15.1 \\
15.2 \\
15.5 \\
15.9\end{array}$ & $\begin{array}{c}\text { (per cu. mm.) } \\
20,500 \\
6,100 \\
6,100 \\
7,000 \\
12,000\end{array}$ \\
\hline \multirow[t]{3}{*}{ Dog No. 27} & \multicolumn{8}{|c|}{ Total hepatectomy } \\
\hline & \multicolumn{2}{|l|}{ Temperature } & \multicolumn{2}{|l|}{ Platelets } & Leukocytes & \multicolumn{3}{|c|}{ Hct. } \\
\hline & \multicolumn{2}{|l|}{$\begin{array}{c}\left({ }^{\circ} C .\right) \\
37 \\
25 \\
20 \\
25 \\
30\end{array}$} & $\begin{array}{c}\text { (per cu. mm.) } \\
248,000 \\
135,500 \\
54,000 \\
133,000 \\
131,000\end{array}$ & & $\begin{array}{c}\text { (per cu. mm.) } \\
13,200 \\
11,000 \\
6,500 \\
7,400 \\
15,900\end{array}$ & & $\begin{array}{l}53.9 \\
57 \\
55.5 \\
55.5 \\
57.5\end{array}$ & \\
\hline \multirow[t]{3}{*}{ Dog No. 28} & \multicolumn{8}{|c|}{ Splenectomy and total hepatectomy } \\
\hline & Temperature & & Platelets & & Leukocytes & & Het. & \\
\hline & $\begin{array}{l}\left({ }^{\circ} C .\right) \\
37 \\
25 \\
20\end{array}$ & & $\begin{array}{c}\text { (per cu. mm.) } \\
221,000 \\
137,000 \\
106,000\end{array}$ & & $\begin{array}{c}\text { (per cu. mm.) } \\
7,950 \\
8,700 \\
6,700\end{array}$ & & $\begin{array}{l}53 \\
58 \\
54\end{array}$ & \\
\hline
\end{tabular}

* All counts from Dogs 27 and 28 were done on blood from the aorta.

Figure 1 is a scattergram which summarizes the effects of organ excision on the platelet counts in hypothermia. Figure 2 is a scattergram of the white cell changes.

\section{DISCUSSION}

In dogs, most of the platelets and white cells disappear during hypothermia, and quickly reappear during rewarming. Are the platelets and white cells which reappear newly formed or are they simply the old platelets and white cells returning to the circulation after a period of sequestration caused by the hypothermia? The bone marrow studies support the sequestration theory. If the reappearance of platelets in the peripheral blood is due to new production, we would expect the megakaryocytes in the marrow to show evidence of increased activity. This was not found in the aspirates and sections of the marrow. The theory of platelet sequestration is further supported by the results of the experiment with platelets tagged with $\mathrm{P}^{32}$. Since 80 per cent of the platelets tagged with $\mathrm{P}^{32}$ prior to hypothermia are still present following rewarming, the disappearance of platelets during hypothermia must be due to sequestration rather than to de-

TABLE IX

Blood counts in a splenectomized dog (number 14) during hypothermia-a comparison of counts from the aorta and high in the inferior vena cava

\begin{tabular}{|c|c|c|c|c|c|c|}
\hline \multirow{2}{*}{$\underset{\text { ture }}{\text { Tempera- }}$} & \multicolumn{3}{|c|}{ Aorta } & \multicolumn{3}{|c|}{ High vena cava } \\
\hline & Platelets & Hemoglobin & Leukocytes & Platelets & Hemoglobin & Leukocytes \\
\hline$\left({ }^{\circ} \mathrm{C}.\right)$ & (per cu. mm.) & (Gm.\%) & (per cu. mm.) & (per cu.mm.) & $(G m . \%)$ & (per cu. mm.) \\
\hline 37 & 360,500 & 16.8 & 11,400 & 257,000 & 17.6 & 9,100 \\
\hline 25 & 149,000 & 18.7 & 7,800 & 115,000 & 18.0 & 6,300 \\
\hline 20 & 58,500 & 18.0 & 6,000 & 49,000 & 18.3 & 5,800 \\
\hline 25 & 98,500 & 16.4 & 3,000 & 135,000 & 16.8 & 5,000 \\
\hline 30 & 145,500 & 17.8 & 5,500 & 205,500 & 17.3 & 5,900 \\
\hline
\end{tabular}


VIllalobos, ADELSON, RILEY, JR., AND CROSBY

TABLE $\mathrm{X}$

Blood counts in a dog during hypothermia following splenectomy and complete hepatectomy-a comparison of counts in the upper and lower vena cava (dog number 29)

\begin{tabular}{|c|c|c|c|c|c|c|}
\hline \multirow{2}{*}{$\begin{array}{c}\text { Tempera- } \\
\text { ture }\end{array}$} & \multicolumn{3}{|c|}{ Upper vena cava } & \multicolumn{3}{|c|}{ Lower vena cava } \\
\hline & Platelets & Het. & Leukocytes & Platelets & Het. & Leukocytes \\
\hline$\left({ }^{\circ} \mathrm{C}.\right)$ & (per cu. $\mathrm{mm}$. ) & & (per cu. mm.) & (per cu. mm.) & & (per cu. mm.) \\
\hline $\begin{array}{l}37 \\
25 \\
20 \\
25 \\
30\end{array}$ & $\begin{array}{l}268,000 \\
211,000 \\
103,500 \\
104,000 \\
143,500\end{array}$ & $\begin{array}{l}54 \\
53 \\
52 \\
49 \\
52\end{array}$ & $\begin{array}{l}6,700 \\
6,000 \\
3,500 \\
5,850 \\
7,550\end{array}$ & $\begin{array}{l}265,000 \\
167,000 \\
110,500 \\
108,500 \\
199,500\end{array}$ & $\begin{array}{l}56 \\
53 \\
52 \\
49 \\
52\end{array}$ & $\begin{array}{r}6,350 \\
5,000 \\
3,650 \\
5,200 \\
10,800\end{array}$ \\
\hline
\end{tabular}

struction. As reported elsewhere (6), the $\mathrm{P}^{32}$ method of tagging platelets gives highly reproducible results. Counts per minute per platelet in successive aliquots of blood agree within 10 per cent. Very little, if any, of the radioactivity is contributed by contamination of the platelet samples by white blood cells or red blood cells, since these elements are nearly completely removed by differential centrifugation. Furthermore, when the donor blood is collected in glass vacuum bottles with $A C D$ anticoagulant, the transfused platelets do not survive and no radioactivity can be detected in the platelets of the recipient three hours post-transfusion, which further demonstrates that red and white cell radioactivity play no role in the platelet radioactivity.

The site of sequestration was not revealed by biopsies of the various organs nor by samples of the capillary blood from these organs. The catheterization studies, however, did indicate where some of the sequestration occurs. During hypothermia, the drop in platelet counts high in the vena cava preceded the drop in the lower vena cava. During rewarming, the rise in platelets high in the inferior vena cava preceded the rise in the lower vena cava. Hepatic vein catheterizations indicated that these differences were due to dilution, with blood low in platelets from the portal circulation, of the samples obtained from the high vena cava. The contribution of the liver to the sequestration was demonstrated by placing catheters in the blood stream flowing into (portal vein) and out of (hepatic vein) the liver. However, since the platelet counts in the portal vein were less than those of the lower vena cava there must have been some sequestration of platelets elsewhere in the portal circulation.

The differences in platelet counts obtained by these catheterization studies in some cases are of small degree. However, the consistency of the direction of the changes suggests that they are significant. Brecher, Schneiderman, and Cronkite (7) have made a statistical evaluation of direct platelet counts by phase microsopy. When two separate pipettes and two separate chambers are used for each determination, the coefficient of variation is 8 , and the 95 per cent confidence limits are \pm 16 per cent. This figure includes both the pipette and the field error. Using this limit many of the platelet differences are significant. For example, in Table IV the differences between platelet count from the aorta and high inferior vena cava are significant at $25^{\circ} \mathrm{C}$. (during cooling), $20^{\circ} \mathrm{C}$., and $25^{\circ} \mathrm{C}$. (during warming). In contrast, the differences between aorta and high inferior vena cava counts after splenectomyhepatectomy (Table VIII, Dog 15) and in the control dog (Table IV) are not significant. The differences between high and low inferior vena cava platelet counts after splenectomy-hepatectomy are also not significant (Table $X$ ). The differences between aorta and hepatic vein counts (Table VII) are significant at the $25^{\circ} \mathrm{C}$. (during cooling), $20^{\circ} \mathrm{C}$., and $25^{\circ} \mathrm{C}$. (during warming) levels. The differences between hepatic vein and portal vein are significant at the $20^{\circ} \mathrm{C}$. and $25^{\circ} \mathrm{C}$. (during warming) levels. However, the differences in platelet counts of Table V and VI, while consistent, are not within 95 per cent confidence limits except for the differences between aorta and hepatic vein counts at the $20^{\circ} \mathrm{C}$. level, and between low inferior vena cava and hepatic vein at the $25^{\circ} \mathrm{C}$. (during cooling) level.

The extirpation experiments indicated that the liver and spleen together were a major site of platelet sequestration. Removal of both organs 


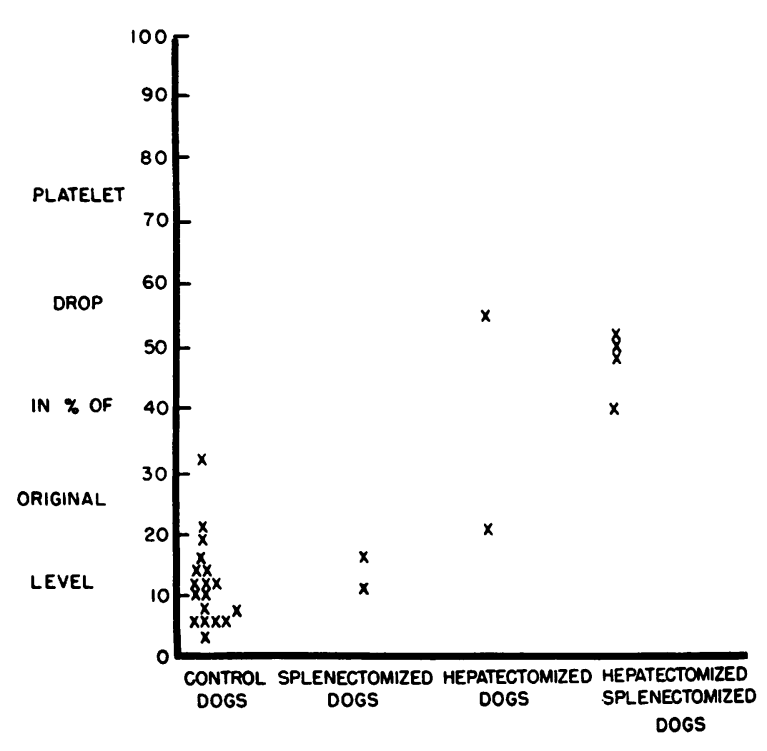

Fig. 1. Response of Platelets to Hypothermia

had a greater effect than the sum of the effects obtained by removing each of them separately. Figure 1 summarizes the effects of organ removal on the thrombocytopenia of hypothermia. This diagram shows that hepatectomy and splenectomy decreased the thrombocytopenia of hypothermia but did not abolish it. There must be other sites of sequestration which we have not demonstrated.

The results of leukocyte studies, while they tended to parallel those of platelet studies, were much less consistent. Figure 2 summarizes the effects of organ removal on the disappearance of white cells.

\section{SUM MARY}

Investigations have been made into the mechanisms of the thrombocytopenia and leukopenia that occur in hypothermic dogs. By tagging platelets with $\mathrm{P}^{32}$, the thrombocytopenia was shown to be caused by sequestration rather than destruction of platelets. This conclusion was supported by bone marrow studies which revealed no evidence of increased formation of platelets.

By sampling the blood in various vessels through polyethylene catheters it was demonstrated that the major site of platelet sequestration is in the portal circulation.

By extirpation it was shown that the liver and spleen play a major role in the sequestration.

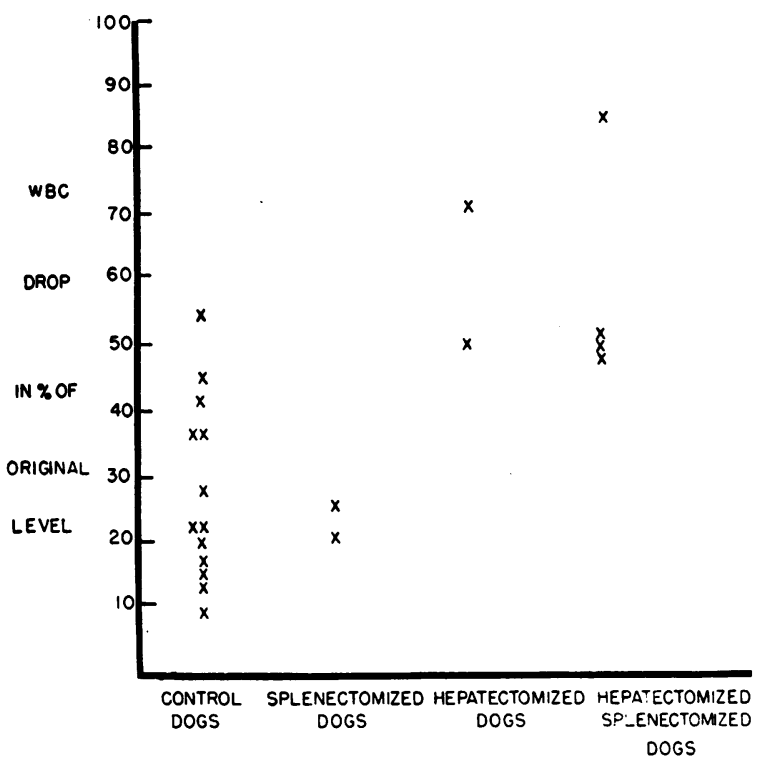

Fig. 2. Response of Leukocytes to Hypothermia

However, since hepatectomized-splenectomized dogs still develop some thrombocytopenia, other areas must also be sites of sequestration.

Changes in the leukocyte counts tended to parallel those of the platelets and were apparently due to similar mechanisms. However, they were not as consistent as those involving the platelets.

\section{REFERENCES}

1. Villalobos, T. J., Adelson, E., and Barila, T. G., Hematologic changes in hypothermic dogs. Proc. Soc. Exper. Biol. \& Med., 1955, 89, 192.

2. Schafer, P. W., Hughes, C. W., and Barila, T. G., Tolerance of the hypothermic normal dog's heart to ventricular fibrillation. Arch. Surg., 1955, 70, 723.

3. Brecher, G., and Cronkite, E. P., Morphology and enumeration of human blood platelets. J. Appl. Physiol., 1950, 3, 365.

4. Crosby, W. H., Munn, J. I., and Furth, F. W., Standardizing a method for clinical hemoglobinometry. U. S. Armed Forces M. J., 1954, 5, 693.

5. Houchin, D. N., Lamanna, A. L., and Lambert, M., Improved technic for capillary hematocrit determination. Med. Technicians Bull., 1955, 6, 171.

6. Adelson, E., Rheingold, J. J., and Crosby, W. H., Studies of platelet survival by an in vivo method of tagging platelets with $\mathrm{P}^{28}$. J. Lab. \& Clin. Med., 1957, 50, 570.

7. Brecher, G., Schneiderman, M., and Cronkite, E. P., The reproducibility and constancy of the platelet count. Am. J. Clin. Path., 1953, 23, 15. 